\title{
A new Savignia from Cretan caves (Araneae: Linyphiidae)
}

\author{
JAN BOSSELAERS \& HANS HENDERICKX \\ ”Dochterland”, R. novarumlaan 2, B-2340 Beerse,Belgium.hortipes@ dochterland.org \\ and \\ Hemelrijkstraat 4, B-2400 Mol, Belgium.hans.henderickx@pandora.be
}

\begin{abstract}
Savignia naniplopi sp. nov. is described from one male and nine female specimens collected in two adjacent limestone caves in Crete. The taxonomy of the Savignia group of species and the relationships of the new species are discussed.
\end{abstract}

Key words: Arachnida, Araneae, Linyphiidae, Savignia, new species, Greece, Crete, cave, troglobiont

\section{Introduction}

Blackwall (1833) created the genus Savignia Blackwall, 1833 in order to accomodate the peculiar linyphiid spider Savignia frontata Blackwall, 1833. Many authors (Simon 1926; Wiehle 1960; Millidge 1977; Roberts 1987; Eskov 1988, 1991; Heimer \& Nentwig 1991) have since spelled the genus name as Savignya but, in spite of the fact that Blackwall dedicated the genus to the entomologist and arachnologist Jules-César Savigny, the original orthography is now used (Platnick 2002). In a later publication, Blackwall (1864: 318) transferred Savignia frontata to Walckenaeria with the following argument: "This spider, on which the genus Savignia was founded, was supposed, when discovered, to have only six eyes. Since then it has been found to possess an additional pair of visual organs, difficult to be discerned, situated towards the front of the apex of its conical cephalic prominence; consequently it had to be removed from the tribe Senoculina, in which a place had been assigned to it, to the genus Walckenaëra, with the spiders of which genus it is connected by marked relations of affinity." Hull (1909) returned Walckenaeria frontata to Savignia. Dahl (1912) described two additional Savignia species, S. conwentzi Dahl, 1912 and S. foveata Dahl, 1912, which were later transferred to other genera. In the second half of the twentieth century, 16 more linyphiid spiders were described in the genus Savignia: $S$. 

tata Paik, 1978 from Korea, S. harmsi Wunderlich, 1980 from Spain, S. superstes Thaler, 1984 from France, S. kartalensis Jocqué, 1985 from the Comoro Islands, S. galeriformis Tanasevich, 1987 from Azerbaidjan, S. basarukini Eskov, 1988, S. borea Eskov, 1988, S. nenilini Marusik, 1988, S. saitoi Eskov, 1988, S. ussurica Eskov, 1988, S. zero Eskov, 1988, S. amurensis Eskov, 1991, S. badzhalensis Eskov, 1991, and S. centrasiatica Eskov, 1991 from the Asiatic part of Russia. S. galeriformis was later transferred to Araeoncus Simon, 1884 by Tanasevich (1990). On the other hand, Tanasevich (1985) transferred Cephalethus birostrum Chamberlin and Ivie, 1947 to Savignia, Eskov (1988) transferred Diplocephalus yasudai Saito, 1986 and Wunderlich (1995) transferred the genus Delorrhipis Simon, 1884, encompassing Delorrhipis fronticornis Simon, 1884 and Delorrhipis erythrocephala Simon, 1908. This adds up to 20 species currently grouped in Savignia (Roewer 1942, 1954; Brignoli 1983; Platnick 1989, 1993, 1997, 2002).

Locket \& Millidge (1953: 289) previously mentioned that Savignia is very close to Diplocephalus Bertkau, 1883. Merrett (1963: 460) confirmed this and discussed the genera Araeoncus Simon, 1884, Dicymbium Menge, 1867, Diplocephalus, Erigonella Dahl, 1901, Glyphesis Simon, 1926 and Savignia as one group based on leg spine characters and genitalic structure, more specifically "the pronounced mesal curvature of the median apophysis, which is also long and bears two dorsal processes at its distal end...". The term "median apophysis" refers to the suprategulum of other authors (Millidge 1977: 2). Millidge (1977) considered the genera Alioranus Simon, 1926, Araeoncus, Delorrhipis, Diastanillus Simon, 1926, Dicymbium, Diplocephalus, Erigonella, Glyphesis, Saloca Simon, 1926 and Savignia so closely related that it would better for them to be united in a single genus. In that case, the genus name Savignia would have priority. All the genera mentioned share a suprategular apophysis of the male palp that "runs downwards along the front of the tegulum and then turns inwards and upwards to give an inner (mesal) arm, so that the suprategular apophysis forms a kind of "hook" above which lies the embolic division" (Millidge 1977: 32). Roberts (1987: 84) agreed with Millidge's view and Wunderlich (1995) subsequently transferred Delorrhipis to Savignia. Eskov (1988: 13) on the other hand prefered to restrict the genus Savignia to a limited number of species displaying a strictly defined set of genitalic characters, e.g. T-shaped embolic division and an embolus which is slightly curved and directed backwards.

In March 1997, the second author explored the Doxa cave on Crete and collected three females of an apparently new linyphiid spider which was then tentatively identified as Diplocephalus sp. (Henderickx 2000). In December 2000, another female was found in the Doxa cave and a male was collected in the Arkalospiliara cave, a few $\mathrm{km}$ from the Doxa cave. In May 2001, five more females were collected from both caves. The longitudinally divided epigyne, the long male cephalic snout bearing two eyes and the male palpal structure clearly support referring this new species to the genus Savignia. The species is described below. 
All measurements are in mm. Specimens were observed and drawn under a binocular microscope equipped with an eyepiece grid. The internal female genitalia were observed and drawn using a compound microscope (Wild M12) equipped with a drawing tube, after clearing the vulva in methyl salicylate. The male palp was also observed with this microscope. Latitude, longitude and altitude above sea level of the collection sites were measured using a Garmin GPS-12 satellite receiver.

Abbreviations used in text: AER, anterior eye row; ALE, anterior lateral eyes; AME, anterior median eyes; PER, posterior eye row; PLE, posterior lateral eyes; PME, posterior median eyes; tm, distance of trichobothrium from metatarsus base (as a fraction of metatarsus length).

Abbreviations of collections: CHH, Collection Hans Henderickx; CJB, Collection Jan Bosselaers; RBINS, Royal Belgian Institute of Natural Sciences, Brussels.

\section{Savignia naniplopi sp. nov. (Figs. 1-12)}

Type material. Holotype male, GREECE: Crete, Iraklion, Marathos, Arkalospiliara cave, $560 \mathrm{~m}, \mathrm{~N} 35^{\circ}$ 20.276' E 24 57.884', 18 Dec 2000, H. Henderickx leg. (RBINS). Paratypes: three females, same locality, 25 May 2001, H. Henderickx and V. Vets leg. (RBINS).

Additional material. GREECE: Crete, Iraklion, Marathos, Doxa cave, $500 \mathrm{~m}, \mathrm{~N} 35^{\circ}$ 20.767' E 24 59.975', three females, 26 March 1997, H. Henderickx and G. Verkerk leg. (CHH), one female, 17 Dec 2000, H. Henderickx leg. (CHH), one female, 24 May 2001, H. Henderickx and V. Vets leg. (CHH), one female, 25 May 2001, H. Henderickx and V. Vets leg. (CJB).

Diagnosis. The new species is similar to Savignia frontata, Savignia fronticornis, Savignia harmsi and Savignia producta through the posession of a long male cephalic snout, but it differs from these species through the shape of the palpal tibial apophysis, details of the male palpal structure, especially the wide, spathulate terminal part, and the fact that the male cephalic snout bears the PME instead of the AME. The epigyne is very similar to the epigyne of Savignia fronticornis (compare Wunderlich 1995: 653, fig. 25) but has the spermathecae closer to each other.

Etymology. The species is named after the gnome (Latin "nanus") Plop, a popular character from children's stories whose cap is similar in shape to the male cephalic snout of the present species.

\section{Description.}

Male. Total length 1.58. Carapace length: 0.71; width: 0.58. Carapace orange-yellow, with a long cephalic snout carrying the PME (Figs. 5-7). Clypeus slanting backwards (Fig. 5), vertical width: 0.13. AME very small, dark, touching each other. ALE small, pearly 
white, widely separated from medians and touching PLE (Fig. 6). Posterior eyes pearly white, small, PME on sides of cephalic snout, halfway from tip (Fig. 5). AER slightly recurved from front as well as from above. PER strongly procurved from front, strongly recurved from above (Fig. 7). Chelicerae orange-yellow, with clearly visible stridulating ridges on sides. Promarginal cheliceral rim with four teeth, the smallest one closest to fang base, the largest one third from fang base. Retromarginal cheliceral rim with three small teeth close to fang base. Sternum orange yellow, shield-shaped, length: 0.47; width: 0.45. Abdomen orange-brown, fading to greyish white in alcohol, without pattern, covered with thin, pointed grey hairs.

Legs orange-yellow, patella I-IV with one terminal dorsal spine, tibia I-II with one basal and one apical dorsal spine, tibia III-IV with one basal dorsal spine. One trichobothrium on metatarsus I-III, none on metatarsus IV.

Leg measurements:

femur patella tibia metat. tarsus total tm

I $\quad \begin{array}{lllllll}0.68 & 0.16 & 0.68 & 0.58 & 0.45 & 2.55 & 0.37\end{array}$

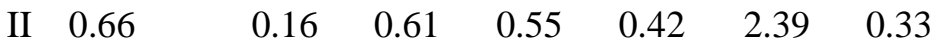

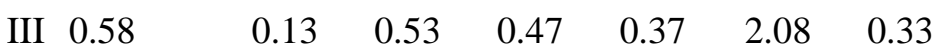

$\begin{array}{llllllll}\text { IV } & 0.76 & 0.16 & 0.74 & 0.63 & 0.42 & 2.71 & -\end{array}$

Male palp as illustrated (Figs. 1-4), tibia with dorsal, curved palpal tibial apophysis (Fig. 4), bulbus with four sclerotised appendages, a thin, pointed one (Fig. 3: a), a tapering one with a hook-shaped tip (Fig. 3: b), a curved one (Fig. 3: c) and a large, broad, spathulate terminal one (Fig. 3: d). Although it is tempting to interpret appendage b (Fig. 3) as the embolic division with the embolus (compare Millidge 1977: fig. 1, fig. 127), careful observation under a compound microscope showed that this structure is solid and has no duct. On the other hand, the large spathulate terminal sclerite d (Fig. 3), when viewed under a compound microscope, can be seen to incorporate a thin duct running along one of the borders its flattened stalk; it probably is the embolus. However, because the opening of the duct could not be seen and because it was preferred not to dissect the single male holotype specimen for this purpose, the palpal sclerites could not be identified with certainty.

Female. Total length 1.66. Carapace length: 0.68; width: 0.55. Carapace orange-yellow, with rounded front (Fig. 12). Clypeus slightly slanting backwards, vertical width: 0.11. AME very small, dark, touching each other. ALE small, pearly white, widely separated from medians and touching PLE (Fig. 12). Posterior eyes pearly white, small, equidistant. AER slightly recurved from front as well as from above. PER slightly procurved from front, straight from above. Chelicerae orange-yellow, with clearly visible stridulating ridges on sides. Promarginal cheliceral rim with four teeth, the smallest one closest to fang base, the largest one third from fang base. Retromarginal cheliceral rim with three small teeth close to fang base. Sternum orange yellow, shield-shaped, length: 0.42; width: 0.42.

Abdomen orange-brown (Fig. 12), fading to greyish white in alcohol, without pattern, covered with thin, pointed grey hairs. 

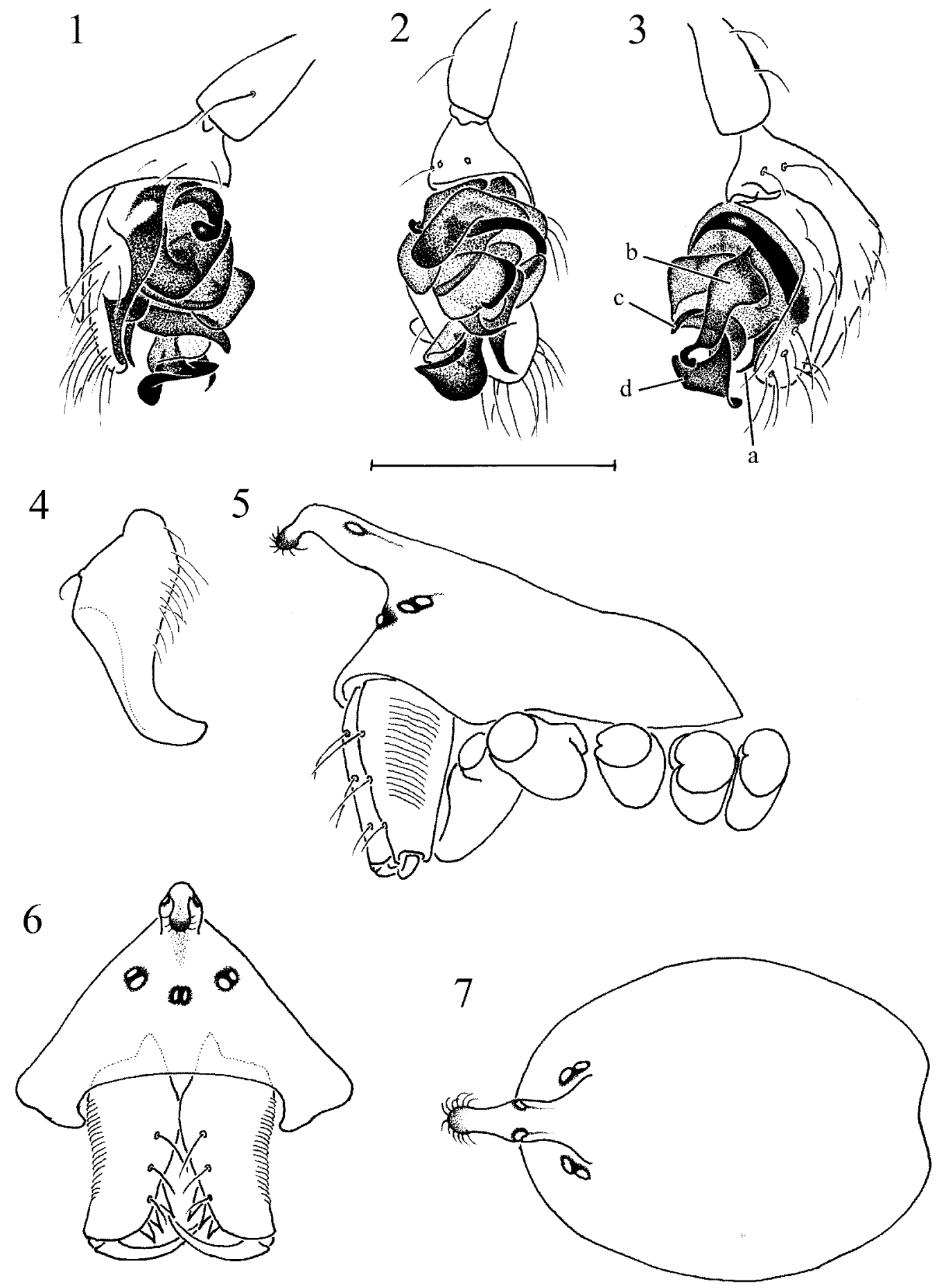

FIGURES 1-7. Savignia naniplopi sp. nov., male holotype. 1, male palp, retrolateral view; 2, male palp, ventral view; 3, male palp, prolateral view, see text for explanation of appendages a-d; 4, male palpal tibia, dorsal view; 5, male carapace, lateral view; 6, male carapace, frontal view; 7, male carapace, dorsal view. Scale bar: 1-4, $0.30 \mathrm{~mm} ; 5-7,0.40 \mathrm{~mm}$. 
Legs orange-yellow, patella I-IV with one terminal dorsal spine, tibia I-II with one basal and one apical dorsal spine, tibia III-IV with one basal dorsal spine. One trichobothrium on metatarsus I-III, none on metatarsus IV.

Leg measurements:

$\begin{array}{llllllll} & \text { femur } & \text { patella } & \text { tibia } & \text { metat. } & \text { tarsus } & \text { total } & \text { tm } \\ \text { I } & 0.74 & 0.16 & 0.63 & 0.57 & 0.42 & 2.51 & 0.41 \\ \text { II } & 0.68 & 0.16 & 0.53 & 0.53 & 0.42 & 2.31 & 0.34 \\ \text { III } & 0.58 & 0.16 & 0.45 & 0.47 & 0.37 & 2.03 & 0.33 \\ \text { IV } & 0.76 & 0.16 & 0.71 & 0.60 & 0.42 & 2.66 & -\end{array}$

Epigyne as illustrated (Figs. 8-10), with longitudinal median fissure. Vulva (Fig. 11) with globular, thick-walled, almost adjacent spermathecae.

Distribution. Only known from two caves in the vicinity of Marathos, Crete.
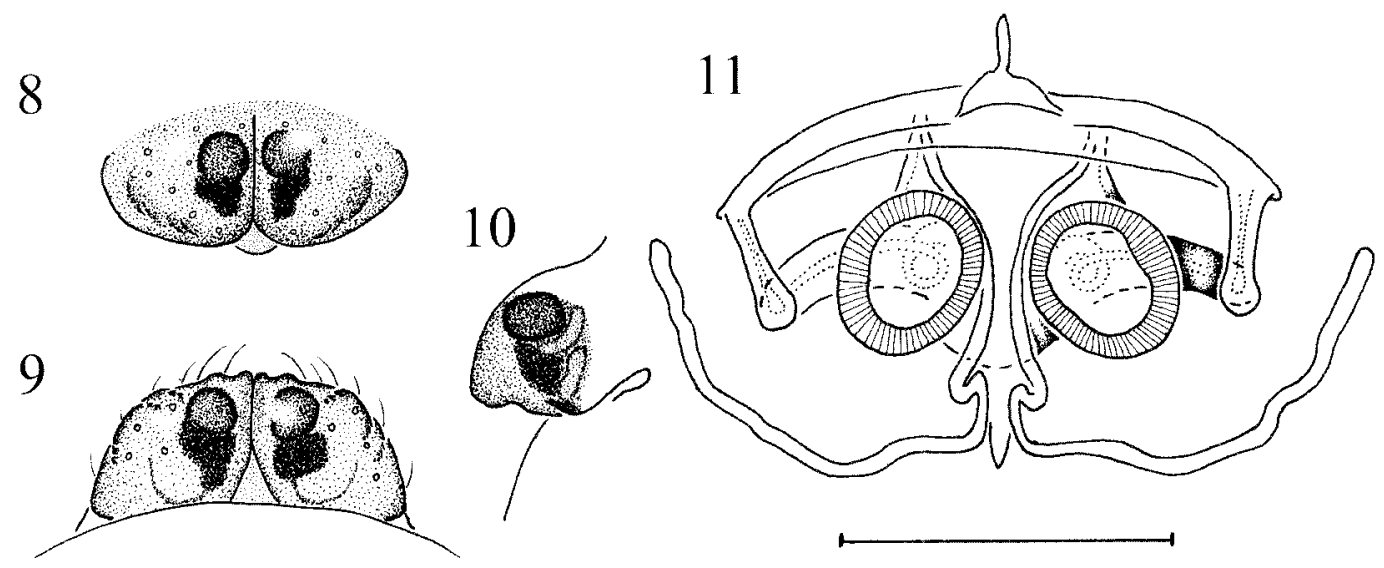

FIGURES 8-11. Savignia naniplopi sp. nov., female paratype. 8, epigyne, ventral view; 9, epigyne, posterior view; 10, epigyne, lateral view; 11, cleared vulva, ventral view. Scale bar: 8-10, 0.30 mm; $11,0.13 \mathrm{~mm}$.

\section{Discussion}

The shape of the male carapace and the genitalic morphology of Savignia naniplopi allow the placement of the new taxon in the Savignia species group as defined by Millidge (1977). The new species seems to be closest to Savignia fronticornis. To date specimens have only been collected from the Doxa and Arkalospiliara caves, two limestone caves in the vicinity of Marathos, Crete. The entrances to these caves are situated at opposite sides of a hill, separated from each other by a distance of about $4 \mathrm{~km}$. The enigmatic pseudoscorpion Neobisium schawalleri Henderickx, 2000 has also been collected from these caves only (Henderickx 2000). It is likely that both caves are connected throug a network 
of subterranean cracks and fissures which constitute a special biotope, accomodating a number of endemic troglophilous life forms with restricted distributions.

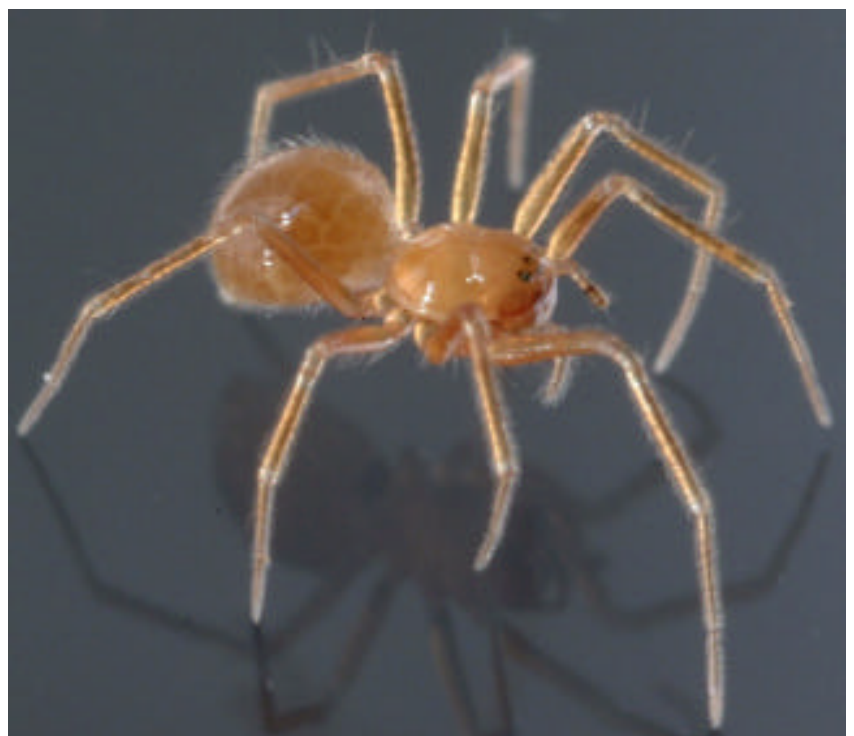

FIGURE 12. Savignia naniplopi sp. nov., female paratype. 12, habitus photograph of living specimen.

\section{Acknowledgements}

Thanks are due to Gijs Verkerk and Vik Vets who assisted the second author in his exploration of the caves near Marathos in 1997 and 2001, respectively. The authors are also grateful to Peter Jäger, Jason Dunlop and an anonymous referee, who gave valuable comments that helped improve the manuscript.

\section{References}

Blackwall, J. (1833) Characters of some undescribed genera and species of Araneidae. London and Edinburgh Philosophical Magazine J. Science, (3)3, 104-112.

Blackwall, J. (1864) A history of the spiders of Great Britain and Ireland. Part II. Ray Society, London, 175-384.

Brignoli, P.M. (1983) A catalogue of the Araneae described between 1940 and 1981. Manchester University Press, Manchester, $755 \mathrm{pp}$.

Dahl, F. (1912) Über die Fauna des Plagefenn-Gebietes. Araneae. In: Conwentz, H. (ed.) Das Plagefenn bei Chorin. Berlin, 575-622.

Eskov, K. Y. (1988) The spider genera Savignya Blackwall, Diplocephalus Bertkau and Archaraeoncus Tanasevitch (Aranei, Linyphiidae) in the fauna of Siberia and the Soviet Far East. Folia entomologica hungarica, 49, 13-39. 
Eskov, K. Y. (1991) Spiders of the genus Savignya (s. str.) (Aranei, Linyphiidae) in the fauna of the Far East and central Asia. Zoologicheskii Zhurnal, 70(5), 140-144.

Heimer, S. \& Nentwig, W. (1991) Spinnen Mitteleuropas. Paul Parey Verlag, Berlin, 543 pp.

Henderickx, H. (2000) Neobisium (Ommatoblothrus) schawalleri sp. nov., a new troglobitic pseudoscorpion from Crete (Arachnida: Pseudoscorpiones: Neobisiidae). Phegea, 28(2), 75-80.

Hull, J. E. (1909) Notes on spiders. Transactions of the Natural History Society of Northumberland (N.S.), 3(2), 446-451.

Locket, G. \& Millidge, A. (1953) British Spiders. Vol II. Ray Society, London, 449 pp.

Merrett, P. (1963) The palpus of male spiders of the family Linyphiidae. Proceedings of the Zoological Society of London, 140, 347-467.

Millidge, A. (1977) The conformation of the male palpal organs of Linyphiid spiders, and its application to the taxonomic and phylogenetic analysis of the family (Araneae: Linyphiidae). Bulletin of the British arachnological Society, 4(1), 1-60.

Platnick, N. (1989) Advances in spider taxonomy 1981-1987. Manchester University Press, Manchester, $673 \mathrm{pp}$.

Platnick, N. (1993) Advances in spider taxonomy 1988-1991. The New York Entomological Society and The American Museum of Natural History, New York, 846 pp.

Platnick, N. (1997) Advances in spider taxonomy 1992-1995. The New York Entomological Society and The American Museum of Natural History, New York, 976 pp.

Platnick, N. (2002) The world spider catalog, version 3.0. http://research.amnh.org/entomology/ spiders/catalog81-87/INTRO3.html.

Roberts, M. (1987) The spiders of Great Britain and Ireland. Volume 2. Harley Books, Colchester, $204 \mathrm{pp}$.

Roewer, C.F. (1942) Katalog der Araneae von 1758 bis 1940. 1. Band. Kommissionsverlag von "NATURA", Bremen, 1040 pp.

Roewer, C.F. (1954) Katalog der Araneae von 1758 bis 1940, bzw. 1954. 2. Band. Royal Belgian Institute for Natural Sciences, Brussels, $1751 \mathrm{pp}$.

Simon, E. (1926) Les arachnides de France. Synopsis générale et catalogue des espèces françaises de l'ordre des Araneae. Tome sixième, deuxième partie. Encyclopédie Roret, Paris, 309-532.

Tanasevitch, A. V. (1985) A study of spiders (Aranei) of the polar Urals. Trudy zoologicheskovo Instituta Leningrad, 139, 52-62.

Tanasevitch, A. V. (1990) The spider family Linyphiidae in the fauna of the Caucasus (Arachnida, Aranei). In: B. R. Striganova (ed.) Fauna nazemnykh bespozvonochnykh Kavkaza. Akademia Nauk, Moscow, 5-114.

Wiehle, H. (1960) Die Tierwelt Deutschlands. 47 Teil. Spinnentiere oder Arachnoidea (Araneae). XI. Micryphantidae-Zwergspinnen. Gustav Fischer Verlag, Jena, 1-620.

Wunderlich, J. (1995) Zur Taxonomie europäischer Gattungen der Zwergspinnen (Arachnida: Araneae: Linyphiidae: Erigoninae). Beiträge zur Araneologie, 4, 643-654. 